\title{
Synergistic Interactions between Cannabinoids and Environmental Stress in the Activation of the Central Amygdala
}

\author{
Sachin Patel', Benjamin F Cravatt ${ }^{2}$ and Cecilia J Hillard*, \\ 'Department of Pharmacology and Toxicology, Medical College of Wisconsin, Milwaukee, WI, USA; ${ }^{2}$ The Skaggs Institute for Chemical Biology \\ and Department of Cell Biology, The Scripps Research Institute, San Diego, CA, USA
}

\begin{abstract}
Anxiety and panic are the most common adverse effects of cannabis intoxication; reactions potentiated by stress. Data suggest that cannabinoid $\left(\mathrm{CB}_{1}\right)$ receptor modulation of amygdalar activity contributes to these phenomena. Using Fos as a marker, we tested the hypothesis that environmental stress and $\mathrm{CB}_{\text {I }}$ cannabinoid receptor activity interact in the regulation of amygdalar activation in male mice. Both $30 \mathrm{~min}$ of restraint and $\mathrm{CB}_{\text {I }}$ receptor agonist treatment $\left(\Delta^{9}\right.$-tetrahydrocannabinol $(2.5 \mathrm{mg} / \mathrm{kg})$ or CP55940 (0.3 mg/kg); by i.p. injection) produced barely detectable increases in Fos expression within the central amygdala (CeA). However, the combination of restraint and $C B_{1}$ agonist administration produced robust Fos induction within the CeA, indicating a synergistic interaction between environmental stress and $C_{1}$, receptor activation. An inhibitor of endocannabinoid transport, AM404 ( $10 \mathrm{mg} / \mathrm{kg}$ ), produced an additive interaction with restraint within the CeA. In contrast, fatty acid amide hydrolase (FAAH) inhibitor-treated mice (URB597, I mg/kg) and $\mathrm{FAAH}^{-1-}$ mice did not exhibit any differences in amygdalar activation in response to restraint compared to control mice. In the basolateral (BLA) and medial amygdala, restraint stress produced a low level of Fos induction, which was unaffected by cannabinoid treatment. Interestingly, the $C_{1}$, receptor antagonist SRI4I7I6 dose-dependently increased Fos expression in the BLA and CeA. These data suggest the $\mathrm{CeA}$ is an important neural substrate subserving the interactions between cannabinoids and environmental stress, and could be relevant to understanding the context-dependent emotional and affective changes induced by marijuana intoxication and the role of endocannabinoid signaling in the modulation of amygdalar activity.
\end{abstract}

Neuropsychopharmacology (2005) 30, 497-507, advance online publication, 28 July 2004; doi:I 0. I 038/sj.npp. 1300535

Keywords: marijuana; $\mathrm{CB}_{\text {I }}$ receptor; Fos; restraint; FAAH; endocannabinoid; anandamide; 2-AG; anxiety

\section{INTRODUCTION}

The subjective effects of cannabis intoxication include euphoria, relaxation and impaired cognition, and, under certain circumstances, anxiety, panic, and overt psychosis (Abel, 1971; Szuster et al, 1988; Adams and Martin, 1996; Thomas, 1996; Degenhardt et al, 2001). Data suggest that some of these effects are dependent upon environmental context, basal levels of anxiety, and previous drug experience (Jones, 1971; Carlin et al, 1972; Szuster et al, 1988). In particular, adverse reactions such as anxiety and panic induced by cannabis are more common in drug-naïve subjects and in novel or stressful environmental situations. For example, $\Delta^{9}$-tetrahydrocannabinol (THC)-induced an-

\footnotetext{
*Correspondence: Dr CJ Hillard, Department of Pharmacology and Toxicology, Medical College of Wisconsin, 8701 Watertown Plank Road, Milwaukee, WI 53226, USA, Tel: + I 4144568493 , Fax: + | 4|4 456 6545, E-mail: chillard@mcw.edu

Received II March 2004; revised I 4 June 2004; accepted 17 June 2004 Online publication: 29 June 2004 at http://www.acnp.org/citations/ Npp06290404I I0/default.pdf
}

xiety reactions in humans are potentiated by oral surgery procedures and during cognitive tasks accompanied by experimenter harassment (Gregg et al, 1976; Naliboff et al, 1976). Consistent with these observations, the most common reasons given for cessation of cannabis use are anxiety and panic reactions (symptoms reported in as much as $20 \%$ of subjects); however, the most common reasons given for continued cannabis use in long-term users are relaxation and reduced tension (Szuster et al, 1988; Thomas, 1996; Reilly et al, 1998). These data suggest that appropriate modulation of cannabinoid systems could have anxiolytic actions in humans. Although adverse anxiety and panic reactions severely limit the clinical utility of direct $\mathrm{CB}_{1}$ agonists, recent preclinical data suggest that pharmacological modulation of endogenous cannabinoid (eCB) systems could represent a novel approach to the treatment of anxiety-related neuropsychiatric disorders (Marsicano et al, 2002; Kathuria et al, 2003).

Consistent with human data, dose- and environmentdependent effects of cannabinoids have also been reported in the animal literature. Low doses of THC and synthetic 
cannabinoids produce anxiolytic effects in laboratory rodents, whereas higher doses produce anxiety-like behaviors and activation of the hypothalamic-pituitary-adrenocortical axis (Manzanares et al, 1999; Giuliani et al, 2000; Berrendero and Maldonado, 2002; Marin et al, 2003). In addition, the expression of anxiety-like behaviors and associated biochemical alterations induced by THC are facilitated by exposure to novel or stressful environments ( $\mathrm{Ng}$ et al, 1973; MacLean and Littleton, 1977). Taken together, these data suggest strong interactions among cannabinoids, anxiety, and environmental stress; however, the neural substrates subserving these interactions have only begun to be explored (MacLean and Littleton, 1977; Onaivi et al, 1995; McGregor et al, 1998).

Anatomical, cellular, and functional evidence suggests that the amygdala plays a key role in emotional and affective changes experienced during cannabis intoxication, and could contribute to the interaction of cannabinoids with environmental stressors. The basolateral complex of the amygdala (BLA) receives and integrates sensory information from the cortex and thalamus, and under appropriate circumstances can activate specific output structures including the central nucleus of the amygdala (CeA) (Davis, 2002; Sah et al, 2003). Projections from the CeA to hypothalamic and brainstem structures contribute to the behavioral and physiological activation associated with emotionally salient environmental stimuli (Davis, 2002). High levels of $\mathrm{CB}_{1}$ cannabinoid receptors are expressed by a subset of cholecystokinin (CCK)-positive GABAergic interneurons within the BLA (McDonald and Mascagni, 2001). $\mathrm{CB}_{1}$ receptors are also expressed by BLA pyramidal neurons, but at lower levels (McDonald and Mascagni, 2001). $\mathrm{CB}_{1}$ receptors have also been reported within the $\mathrm{CeA}$, but neurochemical characterization within this region is lacking (Matsuda et al, 1993; Tsou et al, 1998). Activation of $\mathrm{CB}_{1}$ receptors within the BLA decreases both GABAergic and glutamatergic neurotransmission via presynaptic inhibition of neurotransmitter release (Katona et al, 2001; Azad et al, 2003). However, $\mathrm{CB}_{1}$ activation in the CeA does not modulate GABAergic transmission, and effects on glutamatergic transmission have not been studied (Katona et al, 2001). Similarly, no data regarding the cellular effects of cannabinoids within the medial amygdala (MeA) are available. Functionally, it has been shown that systemic administration of $\mathrm{CB}_{1}$ agonists induces robust Fos expression within the CeA (McGregor et al, 1998; Arnold et al, 2001), and direct injection of THC into this region produces anxiety-like responses in mice (Onaivi et al, 1995). Although complex, the role of $\mathrm{CB}_{1}$ receptor activation in the modulation of amygdalar circuitry provides a framework from which predictions can be made regarding the mechanisms by which cannabinoids affect emotional processes.

Based on the prominent role of $\mathrm{CB}_{1}$ receptor activity in the inhibition of GABAergic transmission within the BLA, Katona et al (2001) have proposed that activation of $\mathrm{CB}_{1}$ receptors results in increased activity of BLA principal projection neurons, which initiates an increase in the activity of their efferent targets, including CeA neurons. They hypothesize that this mechanism could account for the anxiety-like behaviors and robust $\mathrm{CeA}$ activation associated with cannabinoid administration. Since the activity of BLA pyramidal neurons is tightly regulated by local GABAergic transmission (Pare et al, 2003; Quirk and Gehlert, 2003), and $\mathrm{CB}_{1}$ agonists attenuate $\mathrm{GABAergic}$ neurotransmission, an extension of this hypothesis is that cannabinoids effectively reduce the threshold at which salient sensory stimuli activate the BLA-CeA pathway (Katona et al, 2001). Such a mechanism could account for the finding that subthreshold environmental stress or even normally neutral stimuli can acquire emotional or affective salience during cannabis intoxication.

In this study, we tested the hypothesis that cannabinoid administration modulates amygdalar activation in response to mild environmental stress. Our results indicate that cannabinoid agonists can interact synergistically with salient environmental stimuli to facilitate $\mathrm{CeA}$ activation. These data support a role for the CeA in the interactions between cannabinoids and stress. In addition, these findings shed light on the role of eCB signaling in the modulation of amygdalar activity in vivo and could have implications for the development of eCB-based therapeutics for anxietyrelated disorders.

\section{METHODS}

\section{Drugs and Animals}

Male, ICR mice (21-24 g) were used in most experiments (Harlan, Madison, WI). For one experiment, male wild-type (WT, C57/BL6) and FAAH ${ }^{-1-}$ mice derived from homozygous breeders were used (Cravatt et al, 2001). All animals were housed on a 12:12 light/dark cycle with lights on at 0600. Animals had ad lib access to food and water. All experiments were carried out in accordance with the $\mathrm{NIH}$ Guide for the Use and Care of Laboratory Animals.

AM404 was purchased from Tocris Cookson (Ellisville, MO). SR141716 and THC were provided by the NIDA Drug Supply Program (Research Triangle Park, NC). CP55940 was a gift from Pfizer Central Research (Groton, CT). URB597 was purchased from Cayman Chemical (Ann Arbor, MI). All drugs, except URB597, were dissolved in emulphor vehicle (18:1:1, saline:emulphor: ethanol), and delivered by i.p. injection in a volume of $10 \mathrm{ml} / \mathrm{kg}$. URB597 was dissolved in DMSO and delivered in a volume of $50 \mu \mathrm{l}$ by i.p. injection.

\section{Restraint Procedure and Tissue Preparation}

Animals were acclimated to the testing room $24 \mathrm{~h}$ prior to experimentation. Mice were restrained for $30 \mathrm{~min}$ in modified transparent $50 \mathrm{ml}$ plastic conical tubes with numerous small air holes to increase ventilation; control animals were left undisturbed in their home cage. One end of the conical tube was closed using the screw top, while the other end was removed and a tight gauze plug inserted after the animals were placed inside. Animals were placed on the bench top for the restraint period. Drugs were administered at given times prior to restraint (see Figure 1 for schematic depiction of experimental protocol). The direct $\mathrm{CB}_{1}$ receptor agonists THC (2.5 mg/kg) and CP55940 (0.3 mg/ $\mathrm{kg}$ ) and the $\mathrm{CB}_{1}$ receptor antagonist SR141716 $(5 \mathrm{mg} / \mathrm{kg})$ were administered $30 \mathrm{~min}$ prior to restraint. AM404 has low affinity for $\mathrm{CB}_{1}$ receptors, but inhibits neuronal transport of 
vehicle-control and drug-control

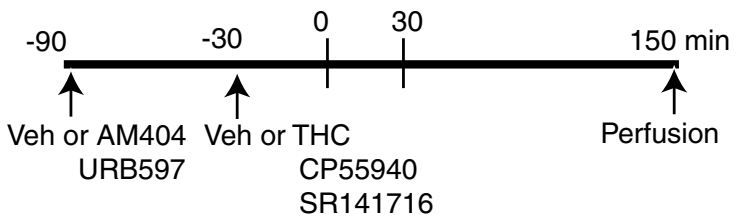

vehicle-restraint and drug-restraint

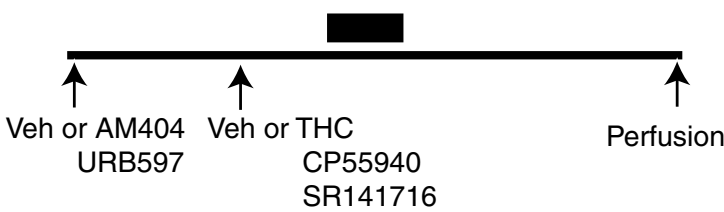

Figure I Schematic diagram of experimental protocol used in drug pretreatment studies. All experiments included four groups $(n=4-5 /$ group): vehicle-control ( $\mathrm{V}-\mathrm{C})$, animals injected with vehicle at the same pretreatment time as the appropriate drug and left in their home cage until perfusion; drug-control (D-C), animals injected with drug and left in their home cage until perfusion; vehicle-restraint $(V-R)$; animals injected with vehicle at the same pretreatment time as the appropriate drug, restrained for $30 \mathrm{~min}$, and returned to their home cage for $2 \mathrm{~h}$, then perfused; drugrestraint (D-R), animals treated with drug and exposed to restraint, returned to their home cage for $2 \mathrm{~h}$, and then perfused. The black rectangle represents restraint exposure. Specific drugs were administered at time points prior to restraint as indicated.

the eCBs $\mathrm{N}$-arachidonylethanolamine (AEA) and 2-arachidonylglycerol (2-AG) (Beltramo et al, 1997; Beltramo and Piomelli, 2000) and inhibits catabolism of AEA by fatty acid amide hydrolase (FAAH) (Jarrahian et al, 2000). AM404 $(10 \mathrm{mg} / \mathrm{kg})$ was administered $90 \mathrm{~min}$ prior to restraint stress to allow for the accumulation of extraneuronal eCBs (Giuffrida et al, 2000). We administered the irreversible FAAH inhibitor, URB597 $(1 \mathrm{mg} / \mathrm{kg}), 90 \mathrm{~min}$ prior to restraint, a time point at which brain AEA content is elevated (Kathuria et al, 2003). We used a maximal dose of URB597 to minimize the possibility of a false negative result.

After 30 min of restraint, animals were placed back in their home cage for $2 \mathrm{~h}$, at which time they were anesthetized with isoflurane, and perfused transcardially with $10 \mathrm{ml}$ PBS, followed by $20 \mathrm{ml}$ of $4 \%$ formaldehyde. After perfusion, brains were removed and incubated in $30 \%$ sucrose for $48 \mathrm{~h}$. Frozen sections ( $35 \mu \mathrm{m}$ thick) were cut on a cryostat and stored in an ethylene glycol solution at $-20^{\circ} \mathrm{C}$ until processed for immunohistochemistry.

\section{Fos Expression Studies}

For quantitative studies, Fos-like immunoreactive (Fos-li) neurons were detected using a rabbit anti-c-Fos antibody (Oncogene, Cambridge, MA; 1:25000 dilution) and the immunohistochemical protocol described previously (Patel and Hillard, 2003). Sections were counterstained with toluidine blue to assist with identification of amygdalar subnuclei. For double-labeled anatomical studies, a goat anti-c-Fos antibody (Santa Cruz Biotechnology, Santa Cruz, CA; $1: 1000$ dilution) was used in combination with the rabbit anti- $\mathrm{CB}_{1}$ antibody raised against the $\mathrm{N}$-terminal 77-amino-acid residues of the $\mathrm{CB}_{1}$ receptor (Affinity Bio Reagents, Golden, CO; 1:100 dilution) (Tsou et al, 1998). Reaction products for Fos and $\mathrm{CB}_{1}$ immunoreactivity $\left(\mathrm{CB}_{1}\right.$-ir) were visualized using appropriate biotin-conjugated secondary antibodies (1:500 dilution; Jackson Immunoresearch, West Grove, PA) followed by processing with the ABC kit (Vector Labs, Burlingame, $\mathrm{CA}$ ) with $\mathrm{Ni} / \mathrm{Co}$ heavy metal intensification to yield a black nuclear reaction product for Fos, and plain $\mathrm{DAB}$ to yield brown reaction product for $\mathrm{CB}_{1}$-ir. For double-labeled fluorescence experiments, a streptavidin-conjugated Alexa 488 (Molecular Probes, Eugene, OR; 1:500 dilution) was used to yield a fluorescent signal for Fos, while glutamic acid decarboxylase 67 (GAD 67) immunoreactivity was detected using a mouse anti-GAD 67 antibody (Chemicon, Temecula, CA; $1: 2000$ dilution), followed by $2 \mathrm{~h}$ incubation in goat antimouse CY3-conjugated secondary antibody (1:500 dilution; Jackson Immunoresearch).

For quantitative analysis, bright-field photomicrographs from matched coronal sections were obtained for each region of interest using a Nikon Eclipse E600 microscope and SPOT advanced imaging software (see Figure 2 for schematic depiction of anatomical regions analyzed). All sections from a given experiment were obtained during the same microscopy session at which the light level and camera exposure times were kept constant. This was performed to minimize variability in the automated cellcounting procedure. The numbers of Fos-li cells within the BLA, MeA, and CeA were determined. A diagram depicting the regions from which cell counts were obtained is shown in Figure 2. Photomicrographs were opened in Image J (available online from the $\mathrm{NIH}$ ) for automated cell counting. Images were converted to 8-bit mono, each region (BLA, CeA, and MeA) was outlined with the freehand draw tool, and the number of Fos-li nuclei was determined within the specified region using the threshold and particle analysis functions of Image J. Particles that met both optical density and size requirements were automatically counted as Fos-li.

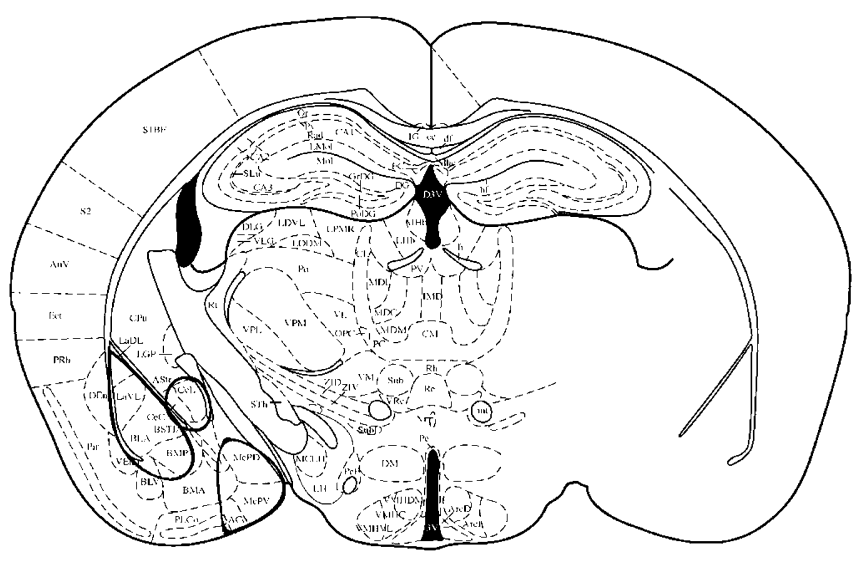

Bregma $-1.70 \mathrm{~mm}$

Figure 2 Schematic diagram of the anatomical regions used for automated cell counting. The BLA, MeA, and CeA were outlined as shown using the freehand draw tool of Image J and separate cell counts were obtained from each region. 


\section{Data Analysis}

Since the number of Fos-li cells in control animals varied somewhat between individual experiments, statistical analyses were confined to comparisons between control and treated animals from the same experiment and immunohistochemical procedure. For each region, data were analyzed by two-way ANOVA factoring restraint condition (control or restrained) and drug treatment (vehicle or drug). When significant main effects of restraint or drug were observed, post hoc Dunnett's test was applied to determine significant differences from the vehicle-control (V-C) group. For the SR141716 dose-response experiment, data were analyzed by one-way ANOVA followed by post hoc Dunnett's test. A $p<0.05$ was considered to be significant throughout. Data are presented as mean \pm SEM number of Fos-li neurons; individual data points are also shown in all figures.

\section{RESULTS}

\section{Anatomical Description of $\mathrm{CB}_{1}$ Receptors and Restraint-Induced Fos Expression within the Amygdala}

$\mathrm{CB}_{1}$-ir was detected within the $\mathrm{BLA}, \mathrm{MeA}$, and $\mathrm{CeA}$ (Figure $3 \mathrm{a}$ and $b$ ). Intensely stained $C_{1}$-positive fibers were observed surrounding cell bodies within the BLA. High $\mathrm{CB}_{1}$ expressing cells that colocalized with GAD 67 were also observed within the BLA, indicating $\mathrm{CB}_{1}$ expression by GABAergic interneurons (not shown). Low levels of cytoplasmic $\mathrm{CB}_{1}$ staining were also observed within BLA pyramidal neurons (not shown). Within the CeA, only light, diffuse staining was observed, which appeared on very fine neuronal processes (see Figure 3a). A similar pattern was observed in the MeA, with the exception that occasionally, intensely labeled beaded fibers were seen in this region (not shown). In general, this description is almost identical to that observed using this antibody in rats (Tsou et al, 1998), and similar to studies using a C-terminal antibody in rats and mice (Katona et al, 2001); the major difference is the detection of immunoreactivity within the $\mathrm{CeA}$ using the $\mathrm{N}$-terminal but not $\mathrm{C}$ terminal antibody. All staining was eliminated by removal of primary antibody from the incubations.

To explore the interactions between environmental stress and cannabinoids in the activation of the amygdala, we utilized a threshold stimulus, $30 \mathrm{~min}$ of restraint, in combination with drug doses that produced little or no effect on Fos expression alone. In general, $30 \mathrm{~min}$ of restraint consistently increased the number of Fos-li neurons within the BLA and $\mathrm{MeA}$, but not CeA (see Figure $3 \mathrm{a}$ and $\mathrm{b}$, and below), indicating that the stimulus was sufficient to increase BLA and MeA activity, but was not of sufficient intensity or duration to increase CeA activity. The distribution of restraint-induced Fos expression within the amygdala can be seen in Figure 3a-c. Double-labeling studies indicate that cells expressing Fos in response to restraint stress within the BLA were not high $\mathrm{CB}_{1}$ expressing (Figure 3b); however, Fos-li neurons within BLA were found to receive perisomatic contacts from $\mathrm{CB}_{1}$-ir fibers (see Figure $3 \mathrm{~b}$ ). Additional double-labeling studies indicate that restraint did not induce Fos expression within GAD

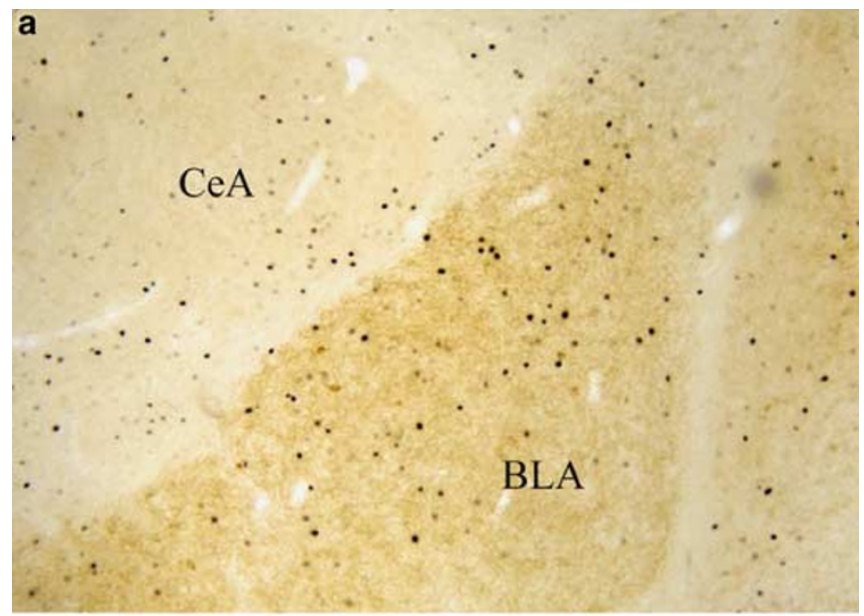

b $\mathrm{CeA}$
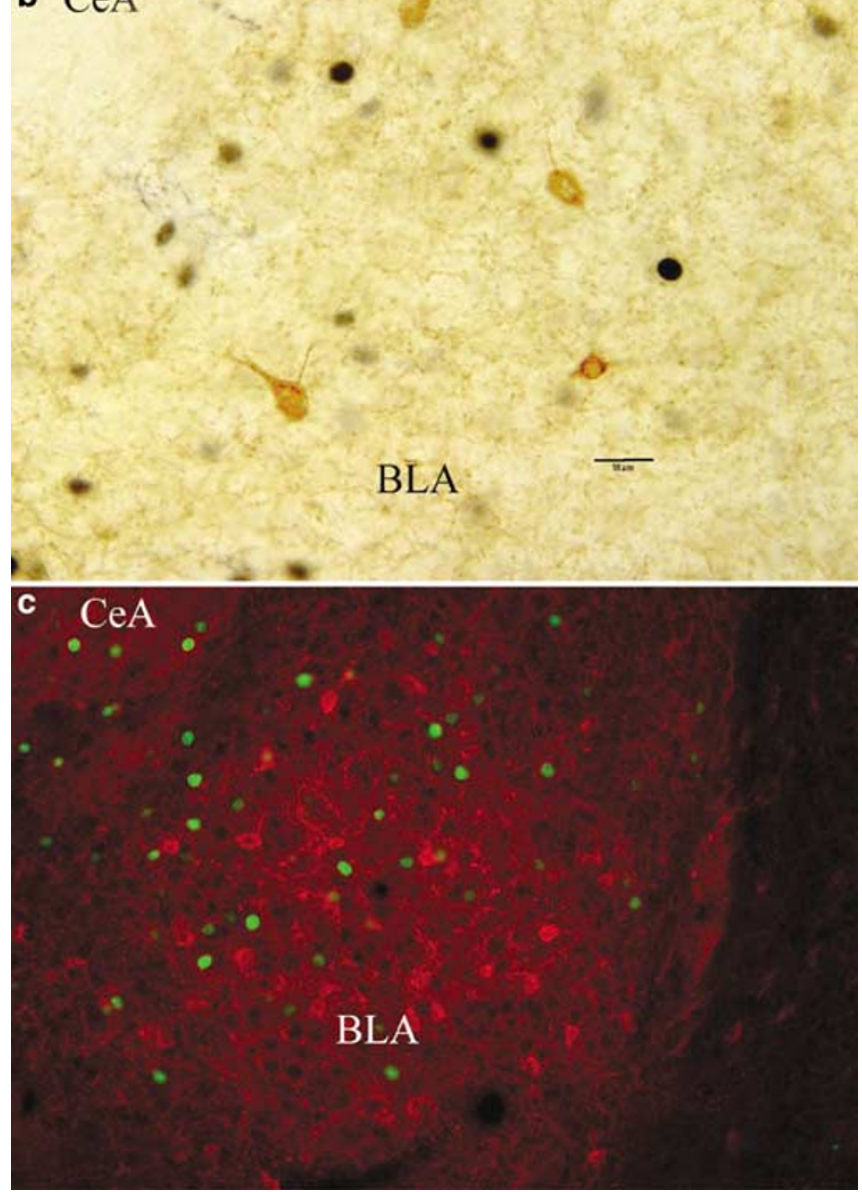

Figure 3 Photomicrographs showing Fos expression within the BLA and $\mathrm{CeA}$ in an animal exposed to $30 \mathrm{~min}$ of restraint. Fos-li cells are visible as black nuclei in (a) and (b), and as green nuclei in (c). (a) Double-stained section showing $\mathrm{CB}_{1}$-ir (brown) and restraint-induced Fos expression within the amygdala. Note the high density of $C_{1}$-ir fibers and high $C B_{1}$ expressing cell bodies within the $B L A$, and the lower level of $C_{1}$-ir within the CeA. (b) Higher magnification view of the BLA. Note the lack of restraint-induced Fos expression within high $C_{1}$ expressing neurons, and

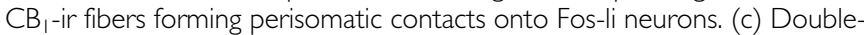
stained section showing GAD 67 staining (red) and restraint-induced Fos expression (green). Note the lack of Fos expression within GAD 67positive neurons. Bar represents approximately $200 \mu \mathrm{m}$ in (a), $50 \mu \mathrm{m}$ in (b), and $100 \mu \mathrm{m}$ in (c). 
67-positive cell bodies within the BLA (Figure 3c). These data indicate that restraint induces Fos expression within BLA pyramidal projection neurons, but not GABAergic interneurons.

\section{Effects of the $\mathrm{CB}_{1}$ Agonists THC and CP55940 on Restraint-Induced Fos Expression}

To determine whether there is an interaction between environmental stress and $\mathrm{CB}_{1}$ receptor activation in the regulation of amygdalar activation, the $\mathrm{CB}_{1}$ receptor agonists THC $(2.5 \mathrm{mg} / \mathrm{kg})$ and CP55940 $(0.3 \mathrm{mg} / \mathrm{kg})$ were administered $30 \mathrm{~min}$ prior to restraint stress. Restraint significantly increased the number of Fos-li cells within the BLA in the THC experiment only. In the absence of restraint, neither THC nor CP55940 significantly increased the number of Fos-li cells within the BLA compared to vehicle-treated control animals (Figures 4 and 5). Pretreatment of mice with CP55940 or THC prior to restraint did not significantly affect Fos expression within the BLA compared to vehicle-pretreated restrained animals (Figures 4 and 5). For the THC experiment, two-way ANOVA revealed a significant effect of drug treatment $\left(\mathrm{F}_{(1,14)}=4.93\right.$, $p=0.043)$ and restraint $\left(\mathrm{F}_{(1,14)}=14.91, p=0.0017\right)$ but no interaction $\left(\mathrm{F}_{(1,14)}=0.61, p=0.45\right.$, NS). For the CP55940 experiment, two-way ANOVA revealed a significant effect of restraint $\left(\mathrm{F}_{(1,15)}=16.94, p=0.0009\right)$ but not drug $\left(\mathrm{F}_{(1,15)}=0.33, p=0.58, \mathrm{NS}\right)$, and no significant interaction $\left(\mathrm{F}_{(1,15)}=3.70, p=0.75\right.$, NS).

The effects of THC and CP55940 on restraint-induced Fos expression within the MeA were also examined. Restraint
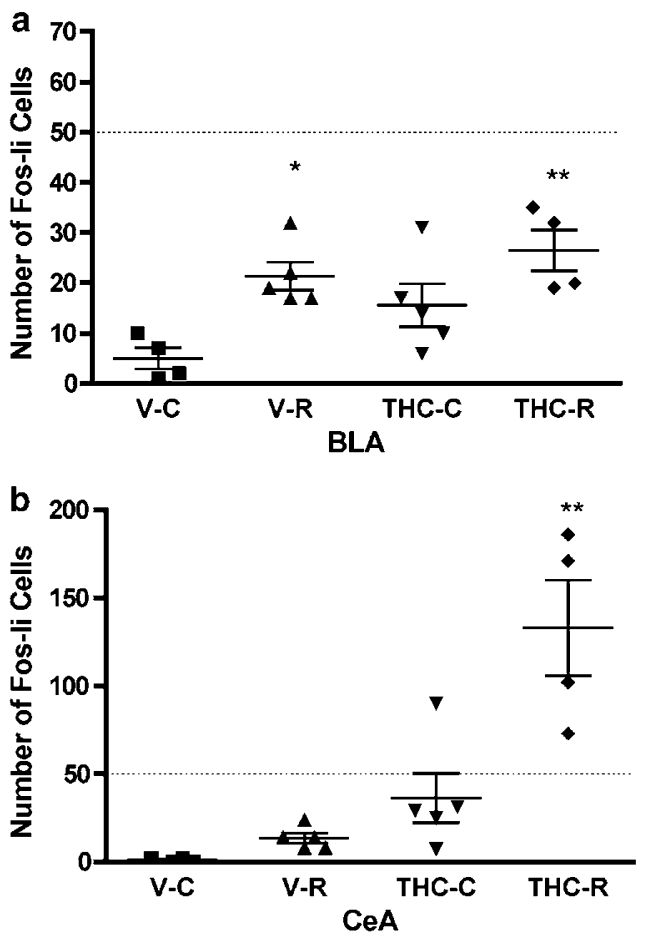

Figure 4 Interactions between THC $(2.5 \mathrm{mg} / \mathrm{kg})$ and $30 \mathrm{~min}$ restraint stress in the expression of Fos within the BLA (a) and CeA (b). *p $<0.05$, ${ }^{*} *{ }^{*}<<0.0$ I, significantly different from the $\mathrm{V}-\mathrm{C}$ group. Note: some of the $Y$-axes in subsequent figures use a different scale. Therefore, a dashed line is shown at the 50-cell mark for easier comparison among experiments. increased the number of Fos-li cells within the MeA, whereas THC and CP55950 alone had no effect (Table 1). Pretreatment with THC or CP55940 did not affect restraintinduced Fos expression within the MeA (Table 1). For the THC experiment, two-way ANOVA revealed a significant effect of restraint $\left(\mathrm{F}_{(1,11)}=43.5, p<0.0001\right)$ and drug $\left(\mathrm{F}_{(1,11)}=7.3, p=0.02\right)$, but no interaction $\left(\mathrm{F}_{(1,11)}=0.39\right.$, $p=0.55$, NS); for the CP55940 experiment, two-way ANOVA revealed a significant effect of restraint $\left(\mathrm{F}_{(1,16)}=208.7, p<0.0001\right)$ but not drug $\left(\mathrm{F}_{(1,16)}=0.38\right.$, $p=0.54, \mathrm{NS})$, and no interaction $\left(\mathrm{F}_{(1,16)}=2.7, p=0.11, \mathrm{NS}\right)$.

Restraint did not increase the number of Fos-li cells within the CeA. In the absence of restraint, neither THC nor CP55940 significantly increased the number of Fos-li cells within the CeA compared to vehicle-treated control animals (Figures 4 and 5). However, in contrast to the BLA and MeA, pretreatment with THC or CP55940 significantly and
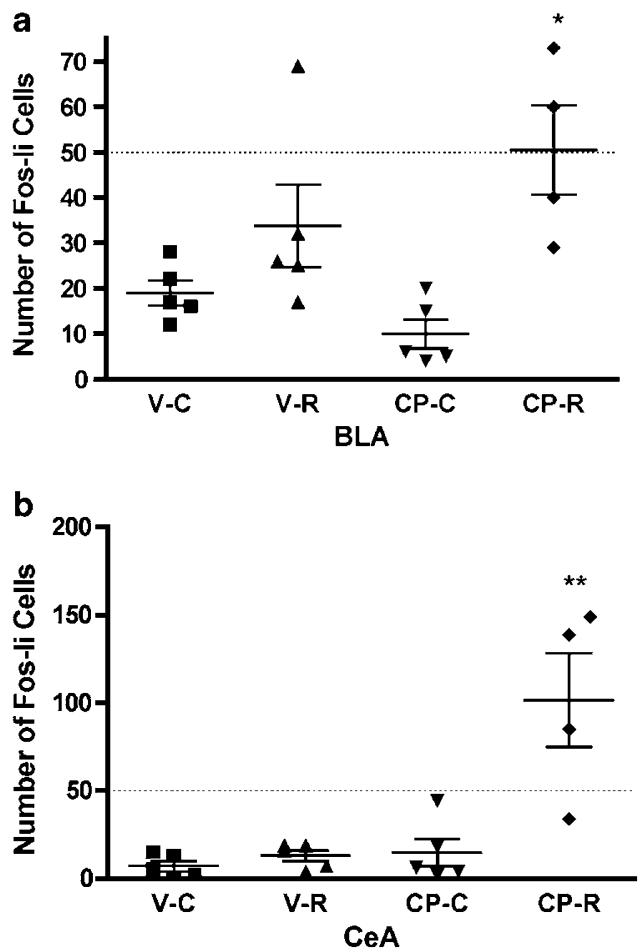

Figure 5 Interactions between CP55940 $(0.3 \mathrm{mg} / \mathrm{kg})$ and $30 \mathrm{~min}$ restraint stress in the expression of Fos within the BLA (a) and CeA (b). $* p<0.05$, *** $<0.01$, significantly different from the $V-C$ group.

Table I Effects of THC (2.5 mg/ $/ \mathrm{kg})$, CP55940 (0.3 mg/kg), AM404 $(10 \mathrm{mg} / \mathrm{kg})$, and SRI $41716(5 \mathrm{mg} / \mathrm{kg})$ on Restraint-Induced Fos Expression within the MeA

\begin{tabular}{lcccc}
\hline & V-C & V-R & D-C & D-R \\
\hline THC & $1.5 \pm 0.86$ & $22.4 \pm 1.7 * *$ & $8.6 \pm 3.5$ & $34.0 \pm 5.6 * *$ \\
CP55940 & $6.8 \pm 1.0$ & $29.4 \pm 1.4 * *$ & $5.0 \pm 1.1$ & $33.4 \pm 2.8 * *$ \\
AM404 & $1.8 \pm 0.5$ & $7.4 \pm 2.6 *$ & $2.0 \pm 0.6$ & $9.8 \pm 3.0 *$ \\
SRI41716 & $1.0 \pm 0.4$ & $13.4 \pm 2.8 * *$ & $1.2 \pm 0.3$ & $11.8 \pm 3.0 * *$
\end{tabular}

All comparisons were made to brain slices assayed for c-Fos expression at the same time. $* p<0.05$, ** $p<0.01$; significantly different from the $\bigvee-C$ group ( $n=4-5 /$ group) 
robustly potentiated restraint-induced Fos expression within the CeA. For the THC experiment, two-way ANOVA revealed a significant effect of restraint $\left(\mathrm{F}_{(1,14)}=14.33\right.$, $p=0.002)$ and drug $\left(\mathrm{F}_{(1,14)}=28.8, p<0.0001\right)$, and a significant interaction $\left(\mathrm{F}_{(1,14)}=8.45, p=0.011\right)$. For the CP55940 experiment, two-way ANOVA revealed a significant effect of restraint $\left(\mathrm{F}_{(1,15)}=15.11, p=0.0015\right)$ and drug $\left(\mathrm{F}_{(1,15)}=16.31, p=0.0011\right)$, and a significant interaction $\left(\mathrm{F}_{(1,15)}=11.46, p=0.0041\right)$. Photomicrographs depicting the synergistic interaction between CP55940 and restraint are shown in Figure 6.

\section{Effects of eCB Transport Inhibitor AM404 on Restraint-Induced Fos Expression}

To explore whether eCBs contribute to stress-induced Fos expression within the amygdala, the $\mathrm{eCB}$ transport inhibitor AM404 was administered prior to restraint stress. Restraint increased the number of Fos-li cells within the BLA, whereas AM404 alone had no effect (Figure 7). Pretreatment of mice with AM404 did not affect restraint-induced Fos expression within the BLA. Two-way ANOVA revealed a significant effect of restraint $\left(\mathrm{F}_{(1,15)}=19.28, p<0.0001\right)$ but not drug $\left(\mathrm{F}_{(1,15)}=1.64, p=0.22\right.$, NS), and no significant interaction $\left(\mathrm{F}_{(1,15)}=0.39, p=0.54, \mathrm{NS}\right)$.

The effects of AM404 on restraint-induced Fos expression with the MeA were also examined. Restraint increased the number of Fos-li cells within the MeA, whereas AM404 alone had no effect (Table 1). Pretreatment with AM404 did not affect restraint-induced Fos expression within the MeA. Two-way ANOVA revealed a significant effect of restraint $\left(\mathrm{F}_{(1,16)}=10.79, p=0.0047\right)$ but not drug $\left(\mathrm{F}_{(1,16)}\right.$ $=0.040, p=0.53$, NS), and no interaction $\left(\mathrm{F}_{(1,16)}=0.29\right.$, $p=0.59, \mathrm{NS})$.

Neither restraint nor AM404 alone significantly increased the number of Fos-li cells within the CeA. In contrast to the BLA and MeA, pretreatment with AM404 significantly potentiated restraint-induced Fos expression within the CeA (Figure 7). Two-way ANOVA revealed a significant effect of restraint $\left(\mathrm{F}_{(1,15)}=15.25, p=0.0014\right)$ and drug $\left(\mathrm{F}_{(1,15)}=14.18, p=0.0019\right)$, and a significant interaction $\left(\mathrm{F}_{(1,15)}=6.00, p=0.027\right)$. Although these data indicate an interaction between AM404 and restraint stress in the induction of Fos, the magnitude of this effect was far less than that seen with direct agonists. In addition, cells expressing Fos in response to the combination of AM404 and restraint were restricted to the capsular division of the CeA.

\section{Effects of FAAH Inhibition on Restraint-Induced Fos Expression}

We determined whether pharmacological or genetic inhibition of FAAH activity interacted with restraint stress to induce Fos expression within the amygdala. URB597 is not soluble in the emulphor vehicle used in all other studies and was therefore delivered in a small volume of DMSO. Intraperitoneal administration of DMSO alone increased Fos expression within the amygdala compared to emulphorinjected animals, consistent with its caustic properties in vivo. However, compared to vehicle-treated animals, URB597 did not increase Fos expression within the BLA

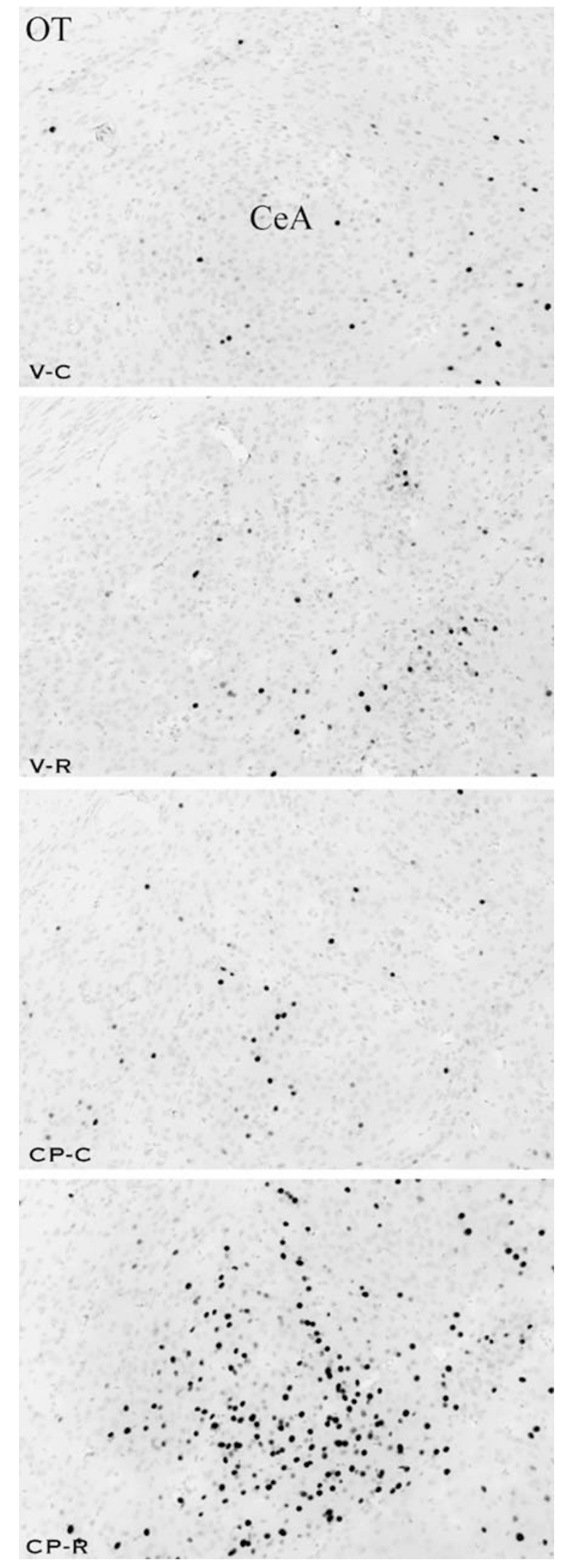

Figure 6 Photomicrographs showing the interaction between CP55940 and restraint stress in the induction of Fos within the CeA. Note the robust Fos induction in the CP-R group only. 

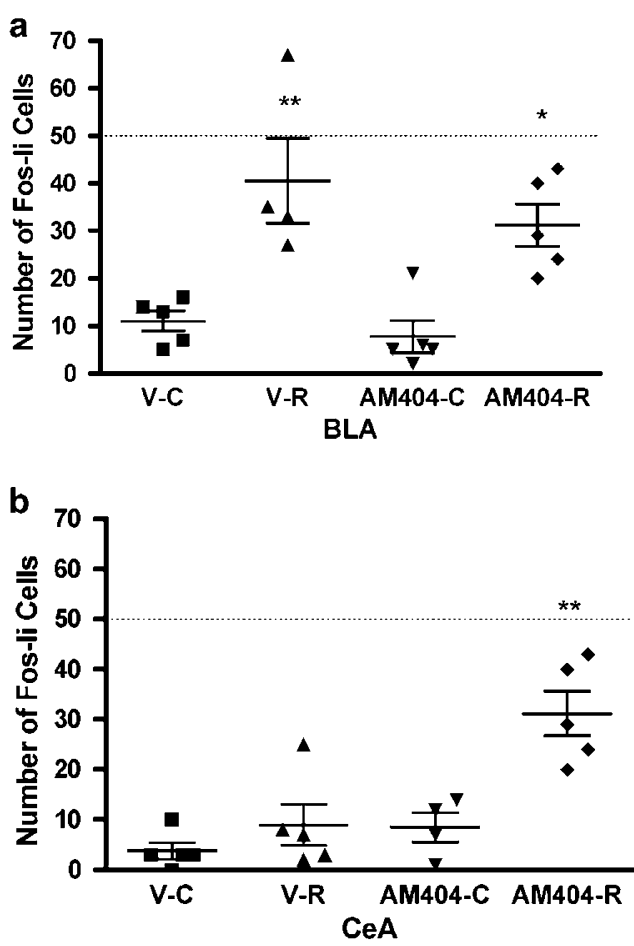

Figure 7 Interactions between AM404 (10 mg/ $/ \mathrm{kg})$ and $30 \mathrm{~min}$ restraint stress in the expression of Fos within the BLA (a) and CeA (b). ${ }^{*} p<0.05$, *** $p<0.01$, significantly different from the $\mathrm{V}-\mathrm{C}$ group.

or CeA. Pretreatment of mice with URB597 did not affect restraint-induced Fos expression within the BLA or CeA (Figure 8). For the BLA, two-way ANOVA revealed a significant effect of restraint $\left(\mathrm{F}_{(1,16)}=15.78, p=0.0011\right)$ but not drug $\left(\mathrm{F}_{(1,16)}=0.065, p=0.80\right.$, NS), and no significant interaction $\left(\mathrm{F}_{(1,16)}=1.77, p=0.20, \mathrm{NS}\right)$. For the CeA, twoway ANOVA revealed no significant effect of restraint $\left(\mathrm{F}_{(1,16)}=4.07, p=0.061\right.$, NS) or drug $\left(\mathrm{F}_{(1,16)}=1.90, p=\right.$ 0.190 , NS), and no significant interaction $\left(\mathrm{F}_{(1,16)}=0.078\right.$, $p=0.783$, NS).

Mice lacking FAAH exhibit elevated endogenous AEA, but not 2-AG, levels, thus representing a genetic model of enhanced AEA signaling (Cravatt et al, 2001). We compared the effects of restraint stress on amygdalar Fos expression between $\mathrm{FAAH}^{-1-}$ and WT mice. In accord with our pharmacological data, no significant difference in restraintinduced Fos expression within either the BLA or CeA was observed between WT and $\mathrm{FAAH}^{-1-}$ mice (Figure 9). For the BLA, two-way ANOVA revealed a significant effect of restraint $\left(\mathrm{F}_{(1,12)}=13.51, \quad p=0.003\right)$ but not genotype $\left(\mathrm{F}_{(1,12)}=1.20, \quad p=0.30, \quad \mathrm{NS}\right)$, and no interaction $\left(\mathrm{F}_{(1,12)}=0.15, p=0.710, \mathrm{NS}\right)$. For the CeA, two-way ANOVA revealed a significant effect of restraint $\left(\mathrm{F}_{(1,11)}=17.3\right.$, $p=0.008)$ but not genotype $\left(\mathrm{F}_{(1,11)}=0.1, p=0.81, \mathrm{NS}\right)$, and no interaction $\left(\mathrm{F}_{(1,11)}=0.41, p=0.63, \mathrm{NS}\right)$.

\section{Effects of the $\mathrm{CB}_{1}$ Receptor Antagonist SR141716 on Restraint-Induced Fos Expression}

To explore whether tonic eCB signaling modulates amygdalar activity, we treated mice with the $\mathrm{CB}_{1}$ receptor antagonist SR141716 (5 and $10 \mathrm{mg} / \mathrm{kg}) 2 \mathrm{~h}$ before perfusion.
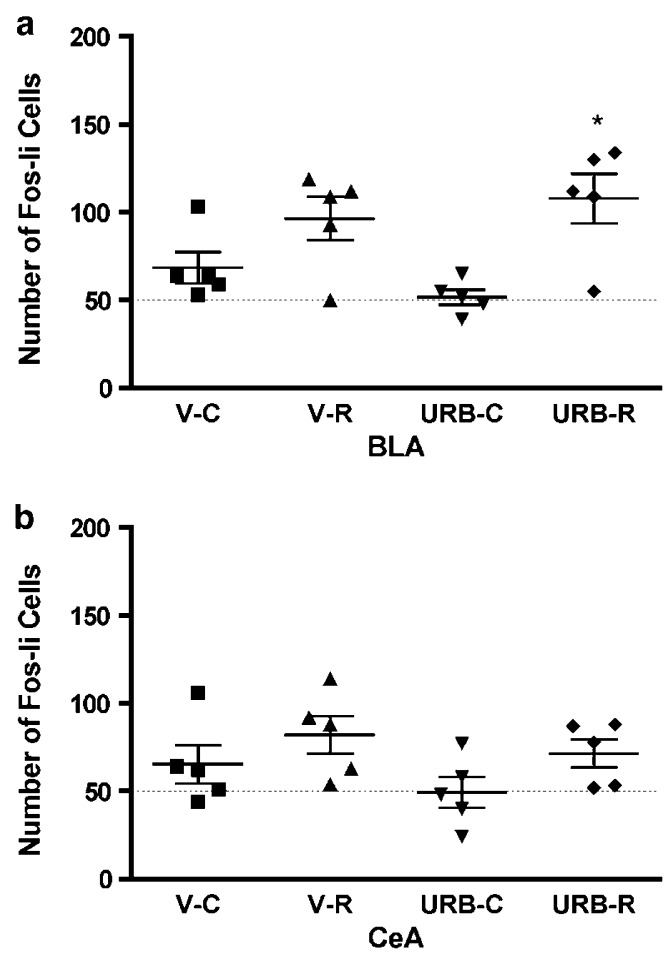

Figure 8 Interactions between URB597 (I mg/kg) and 30 min restraint stress in the expression of Fos within the BLA (a) and CeA (b). $* p<0.05$, significantly different from the $\mathrm{V}$-C group.
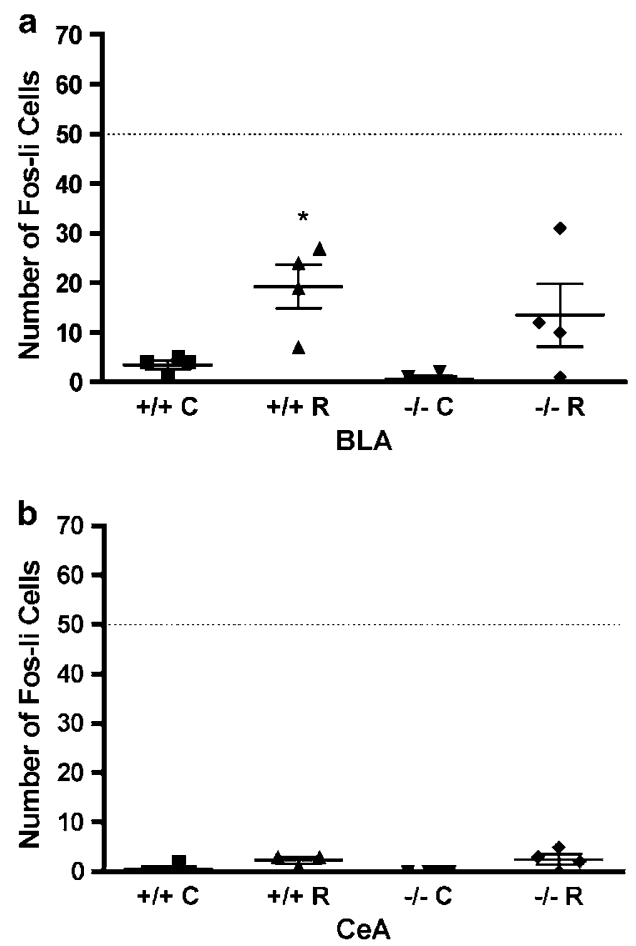

Figure 9 Effects of 30 min restraint stress on Fos expression within the $\mathrm{BLA}$ (a) and $\mathrm{CeA}$ (b) in WT and $\mathrm{FAAH}^{-1-}$ mice. $* p<0.05$, significantly different from the $+I+C$ group. There was no significant effect of genotype on restraint-induced Fos expression within the BLA or CeA.

SR141716 produced a dose-dependent increase in Fos expression within the BLA and CeA (Figure 10). For the BLA, one-way ANOVA revealed a significant effect of 

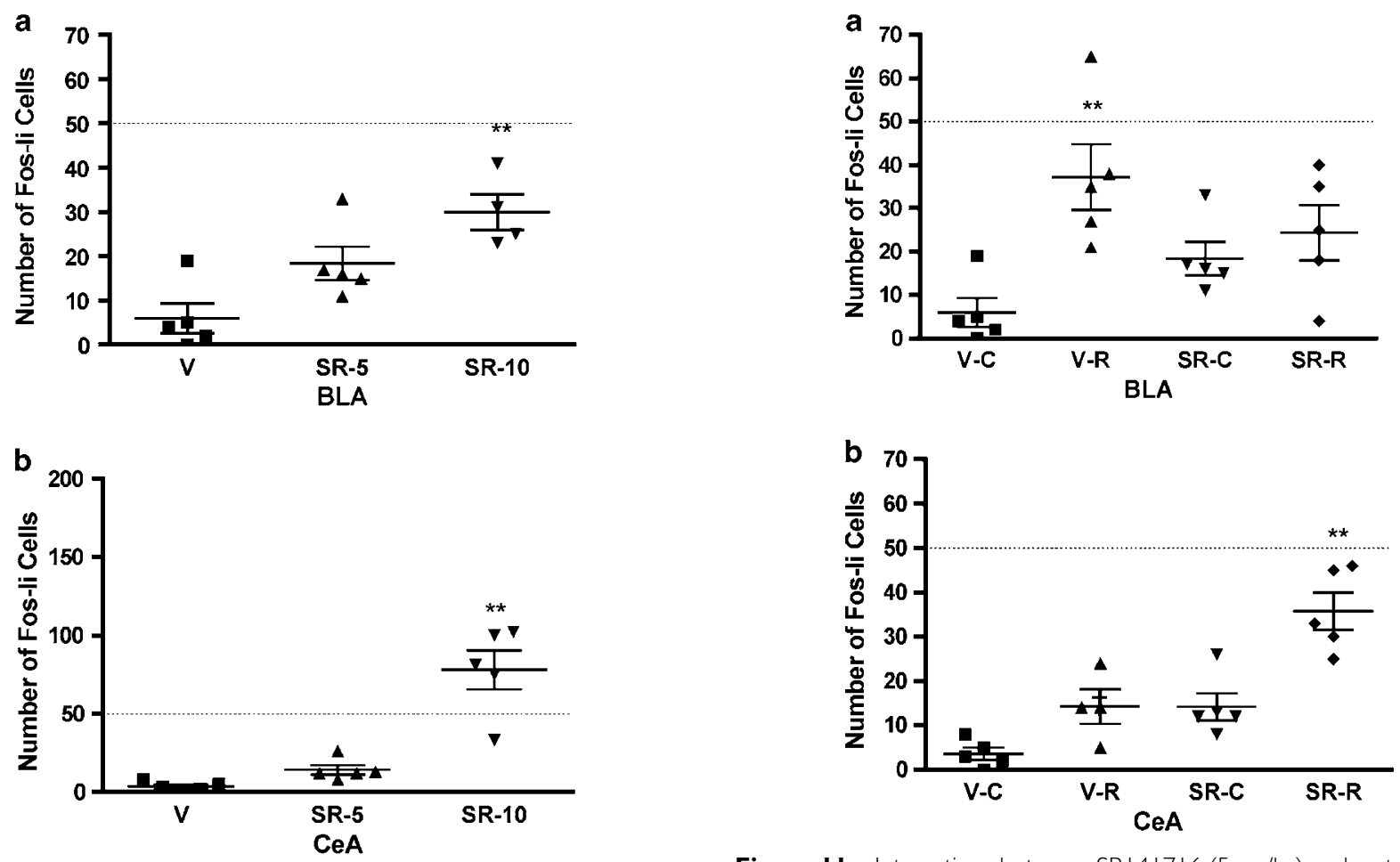

Figure 10 Effects of the $\mathrm{CB}_{1}$ receptor antagonist SRI4I7|6 (5 and $10 \mathrm{mg} / \mathrm{kg}$ ) on Fos expression within the BLA (a) and CeA (b). *** $<0.01$, significantly different from vehicle treatment.

treatment $\left(\mathrm{F}_{(2,11)}=10.0, p=0.0033\right)$. For the CeA, one-way ANOVA revealed a significant effect of treatment $\left(\mathrm{F}_{(2,12)}=29.36, p<0.0001\right)$.

To determine whether there is an interaction between restraint stress and $\mathrm{eCB}$ signaling, we pretreated animals with the $C_{1}$ receptor antagonist SR141716 $(5 \mathrm{mg} / \mathrm{kg})$ $30 \mathrm{~min}$ prior to restraint. Restraint significantly increased the number of Fos-li cells within the BLA and MeA, but not CeA. SR141716 alone did not increase the number of Fos-li cells within the BLA, MeA, or CeA. SR141716 pretreatment significantly affected restraint-induced Fos expression within the BLA but did not significantly affect restraint-induced Fos expression within the CeA or MeA (Figure 11 and Table 1). For the BLA, two-way ANOVA revealed a significant effect of restraint $\left(\mathrm{F}_{(1,16)}=11.20, p=0.004\right)$ but not drug $\left(\mathrm{F}_{(1,16)}=0.003, p=0.97, \mathrm{NS}\right)$, and a significant interaction $\left(\mathrm{F}_{(1,16)}=5.14, p=0.037\right)$. For the CeA, two-way ANOVA revealed a significant effect of restraint $\left(\mathrm{F}_{(1,15)}=24.36, \quad p=0.0002\right)$ and drug $\left(\mathrm{F}_{(1,15)}=24.21\right.$, $p=0.0002)$, but no significant interaction $\left(\mathrm{F}_{(1,15)}=2.80\right.$, $p=0.11$, NS). For the MeA, two-way ANOVA revealed a significant effect of restraint $\left(\mathrm{F}_{(1,15)}=26.31, p=0.0001\right)$ but not drug $\left(\mathrm{F}_{(1,15)}=0.010, p=0.76, \mathrm{NS}\right)$, and no interaction $\left(\mathrm{F}_{(1,15)}=0.16, p=0.69, \mathrm{NS}\right)$.

\section{DISCUSSION}

In order to detect a positive interaction between stress and cannabinoids, efforts were made to choose a stressor that produced a threshold level of Fos expression within the amygdala. Based on preliminary studies, we utilized $30 \mathrm{~min}$

of restraint. This stimulus produced a consistent activation of the BLA and MeA, but not CeA. Similarly, pilot doseresponse studies were used to select doses of drugs that produced little, if any, activation of the amygdala. This combination of stimuli resulted in the detection of synergistic interactions between environmental stress and $\mathrm{CB}_{1}$ receptor agonists in the activation of $\mathrm{CeA}$, but not BLA or $\mathrm{MeA}$, as indexed by a robust induction of Fos protein. Our data also indicate that augmentation of AEA signaling is not sufficient to recapitulate the effects of direct $C_{1}$ agonists on Fos expression within the $\mathrm{CeA}$, a finding that could be relevant to the development of eCB-based therapeutics for anxiety-related disorders. Lastly, our data with SR141716 indicate that tonic $C_{1}$ receptor activation inhibits amygdalar activity under nonstressed conditions.

In general, our data are consistent with the model proposed by Katona et al (2001) that $\mathrm{CB}_{1}$ agonists inhibit BLA GABAergic neurotransmission, which effectively reduces the threshold for activation of the BLA-CeA pathway by salient sensory stimuli. First, consistent with previous studies (Katona et al, 2001), $\mathrm{CB}_{1}$-ir neurons within the BLA were found to be GABAergic, based on colocalization with GAD 67, supporting the role of $\mathrm{CB}_{1}$ receptors in the modulation of GABAergic transmission. Second, neurons that expressed Fos in response to restraint were found to receive perisomatic contacts from $\mathrm{CB}_{1}$-ir fibers, providing an anatomical substrate which is consistent with an effect of $\mathrm{CB}_{1}$ receptor activity on the activation of BLA neurons. Third, our functional data indicate that threshold aversive environmental stimuli induce robust activation of $\mathrm{CeA}$ neurons when combined with threshold doses of direct $\mathrm{CB}_{1}$ receptor agonists. That blockade of $\mathrm{CB}_{1}$ receptors during 
restraint moderated restraint-induced Fos expression within the BLA also supports this hypothesis. Since the restraint responsive neurons within the BLA were determined to be pyramidal projection neurons (based on a lack of colocalization with the GABAergic neuronal marker GAD67), we conclude that $C_{1}$ receptor activation decreases the threshold at which salient stimuli activate the BLA-CeA pathway in vivo.

However, one aspect of the model proposed by Katona et $a l$ is not supported by the present results. The model predicts that stress-induced neuronal activation in the BLA should also be potentiated by $\mathrm{CB}_{1}$ receptor activation, a finding not consistently observed in this study. Several methodological and theoretical possibilities could account for this difference. Methodological issues relate primarily to the use of immediate early gene expression as a marker of neuronal activation. It is possible that the activity of BLA neurons is increased by the combination of cannabinoid agonists and restraint, but the increase is not sufficient to induce detectable Fos expression. Alternatively, neurons that express Fos in response to restraint alone could be more active when restraint is combined with cannabinoid agonist administration, but since these cells would already have been counted as Fos-li, no further increase in the number of Fos-li neurons would be observed.

A more likely explanation is that the assumption of the original model, that the sole site of action of the cannabinoids is the BLA, is not correct. For example, cannabinoid actions within the CeA itself could result in potentiation of stress-induced activation of the CeA. This hypothesis is supported by the presence of $\mathrm{CB}_{1}$ receptors within the CeA (present data; see also Matsuda et al, 1993; Tsou et al, 1998) and the ability of direct injections of THC into CeA to induce anxiety responses in mice (Onaivi et al, 1995). Although the lack of effect of $\mathrm{CB}_{1}$ receptor activation on GABAergic transmission within this region argues against this possibility (Katona et al, 2001), the precise role of $\mathrm{CB}_{1}$ receptor activation in the modulation of $\mathrm{CeA}$ neuronal activity remains to be determined.

Another possibility is that $\mathrm{CB}_{1}$ agonist potentiation of stress-induced $\mathrm{CeA}$ activation involves a trans-synaptic mechanism. For example, GABAergic cells within intercalated cell masses (ICM), which lie at the anatomical interface of the BLA and $\mathrm{CeA}$, generate feedforward inhibition of CeA neurons in response to BLA activation (Royer et al, 1999, 2000), and are regulated by extrinsic glutamatergic afferents from the prefrontal cortex and dopaminergic afferents from the ventral midbrain (Bissiere et al, 2003; Quirk et al, 2003). Therefore, cannabinoid actions within these regions, which are known to occur (French et al, 1997; Gessa et al, 1998; Auclair et al, 2000; Patel and Hillard, 2003), could modulate CeA activity independently of the BLA, via modulation of ICM neuronal activity. Determining the contributions of these potential mechanisms to the effects observed in this study remains an important future goal.

Several issues regarding the pharmacological aspects of the present study also warrant discussion. The in vivo potency difference between THC and CP55940 in the activation of Fos expression within the CeA (less than 10fold) is far less than that predicted by the differences in binding affinity for $\mathrm{CB}_{1}$ receptors (about an 80-fold difference) (Hillard et al, 1995). THC has lower efficacy at $\mathrm{CB}_{1}$ receptor activation compared to CP55940 (Kearn et al, 1999), which further suggests that in vivo differences between THC and CP55940 do not correlate with in vitro pharmacological properties. It is possible that the high affinity and efficacy of CP55940 result in robust receptor internalization and desensitization (Hsieh et al, 1999). In contrast, the relatively low affinity and efficacy of THC could result in less internalization/desensitization and, therefore, be more likely to support continuous receptor signaling. The present data are at odds with those of Arnold et al (2001) in which $0.25 \mathrm{mg} / \mathrm{kg}$ CP55940 produced a robust increase in CeA Fos expression in rats. By contrast, we detected Fos expression within the $\mathrm{CeA}$ at $0.3 \mathrm{mg} / \mathrm{kg}$ CP55940 only when mice were also exposed to restraint. The differences between these results could be attributed to species used; alternatively, the present findings suggest that the rats in the former study were stressed, in addition to cannabinoid-treated. This notion is supported by the fact that the rats in the former study were exposed to behavioral tests and body temperature measurements before perfusion for Fos immunohistochemistry.

We also explored whether augmentation of eCB content interacted with restraint stress in the activation of the amygdala. AM404, administered at a time and dose known to increase AEA content in plasma (Giuffrida et al, 2000), potentiated restraint-induced Fos expression within the $\mathrm{CeA}$, although the magnitude of this increase was far less than that produced by direct $\mathrm{CB}_{1}$ receptor agonists. In contrast, the FAAH inhibitor URB597, administered at a time and dose shown to increase brain AEA content and reduce FAAH activity (Kathuria et al, 2003), did not alter restraint-induced Fos expression within the BLA or CeA. In addition, $\mathrm{FAAH}^{-1-}$ mice, which exhibit highly elevated brain AEA content (Cravatt et al, 2001), did not exhibit a potentiated amygdalar response to restraint compared to WT mice. Taken together, these data strongly suggest that complete lack of FAAH activity, and the associated elevation in AEA content, is not sufficient to mimic the effects of direct $\mathrm{CB}_{1}$ agonists or AM404. This dissociation between FAAH inhibition and $\mathrm{CB}_{1}$ receptor activation on restraintinduced $\mathrm{CeA}$ activity could be relevant to the monophasic, dose-dependent anxiolytic actions of URB597, compared to the biphasic effects of direct cannabinoid agonists on anxiety (Kathuria et al, 2003). Lastly, it is possible that the selective interaction between AM404 and restraint stress, compared to FAAH inhibition, arises from the ability of AM404 to inhibit re-uptake of both AEA and 2-AG, since neither URB597 (Kathuria et al, 2003) nor genetic deletion of FAAH affects brain 2-AG content (unpublished data). In other words, it is possible that the eCB that mediates the effects of AM404 in this assay is 2-AG, not AEA. Another possibility is that the effects of AM404 are mediated via activation of vanilloid VR1 receptors, as it is an agonist of these receptors (Lastres-Becker et al, 2003).

The effects of SR141716 on amygdalar neuronal activity are paradoxical in the light of the effects of $\mathrm{CB}_{1}$ agonists. SR141716 produced a dose-dependent increase in Fos expression within the BLA and $\mathrm{CeA}$, suggesting that $\mathrm{eCB}$ tone suppresses amygdala activity, an effect observed within other limbic regions such as the prefrontal cortex and nucleus accumbens (Alonso et al, 1999; Duarte et al, 2004). 
At least two possibilities could explain the effects of SR141716 on amygdalar activation. First, since $\mathrm{CB}_{1}$ receptor activation has been shown to decrease glutamatergic transmission within the BLA (Azad et al, 2003), SR141716-induced blockade of eCB tone could result in increased glutamatergic transmission, activation of BLA and, subsequently, CeA neurons. This suggestion, however, is not supported by anatomical data, since asymmetrical synapses within the BLA very rarely express $C_{1}$ receptors detected using a C-terminal antibody (Katona et al, 2001). Alternatively, since $\mathrm{CB}_{1}$ receptors are located on CCKpositive interneurons within the BLA (McDonald and Mascagni, 2001), and activation of $\mathrm{CB}_{1}$ receptors can inhibit CCK release from hippocampal slices (Beinfeld and Connolly, 2001), SR141716-induced blockade of eCB tone could result in increased CCK release within the BLA. Since intraamygdala injections of CCK can induce anxiety-like behaviors (Belcheva et al, 1994), and systemic administration of CCK increases Fos expression within the CeA (Day et al, 1994), a CCK-dependent mechanism could subserve the amygdala-activating effects of SR141716 in rodents.

In conclusion, our data clearly support a role for increased CeA activity in the interactions between $\mathrm{CB}_{1}$ receptor agonists and environmental stress, and suggest that eCB signaling tonically suppresses the activity of the BLA-CeA pathway under nonstressed conditions. These findings are generally consistent with the known cellular effects of $\mathrm{CB}_{1}$ receptor activation within the amygdala. The $\mathrm{CeA}$ integrates amygdalar, thalamic, cortical, and brainstem inputs, and projects to limbic, hypothalamic, and autonomic targets. Therefore, we suggest the $\mathrm{CeA}$ could be an important neural substrate relevant to the context-dependent autonomic, affective, and emotional effects of cannabis intoxication in humans.

\section{ACKNOWLEDGEMENTS}

These studies were supported by National Institute of Health Grants R01 DA016967 and F30 DA15575 (SP). We thank Craig T Roelke for excellent technical assistance. We also acknowledge the anonymous reviewer who suggested that increased activity of the CeA could be relevant to the anxiolytic properties of cannabinoids.

\section{REFERENCES}

Abel EL (1971). Changes in anxiety feelings following marihuana smoking. the alternation in feelings of anxiety resulting from the smoking of marihuana (Cannabis sativa L.). Br J Addict Alcohol Other Drugs 66: 185-187.

Adams IB, Martin BR (1996). Cannabis: pharmacology and toxicology in animals and humans. Addiction 91: 1585-1614.

Alonso R, Voutsinos B, Fournier M, Labie C, Steinberg R, Souilhac J et al (1999). Blockade of cannabinoid receptors by SR141716 selectively increases Fos expression in rat mesocorticolimbic areas via reduced dopamine D2 function. Neuroscience 91: 607-620.

Arnold JC, Topple AN, Mallet PE, Hunt GE, McGregor IS (2001). The distribution of cannabinoid-induced Fos expression in rat brain: differences between the Lewis and Wistar strain. Brain Res 921: 240-255.

Auclair N, Otani S, Soubrie P, Crepel F (2000). Cannabinoids modulate synaptic strength and plasticity at glutamatergic synapses of rat prefrontal cortex pyramidal neurons. J Neurophysiol 83: 3287-3293.

Azad SC, Eder M, Marsicano G, Lutz B, Zieglgansberger W, Rammes G (2003). Activation of the cannabinoid receptor type 1 decreases glutamatergic and GABAergic synaptic transmission in the lateral amygdala of the mouse. Learn Mem 10: $116-128$.

Beinfeld MC, Connolly K (2001). Activation of CB1 cannabinoid receptors in rat hippocampal slices inhibits potassium-evoked cholecystokinin release, a possible mechanism contributing to the spatial memory defects produced by cannabinoids. Neurosci Lett 301: 69-71.

Belcheva I, Belcheva S, Petkov VV, Petkov VD (1994). Asymmetry in behavioral responses to cholecystokinin microinjected into rat nucleus accumbens and amygdala. Neuropharmacology 33: 995-1002.

Beltramo M, Piomelli D (2000). Carrier-mediated transport and enzymatic hydrolysis of the endogenous cannabinoid 2-arachidonylglycerol. Neuroreport 11: 1231-1235.

Beltramo M, Stella N, Calignano A, Lin SY, Makriyannis A, Piomelli D (1997). Functional role of high-affinity anandamide transport, as revealed by selective inhibition. Science 277: 1094-1097.

Berrendero F, Maldonado R (2002). Involvement of the opioid system in the anxiolytic-like effects induced by $\operatorname{Delta}(9)$ tetrahydrocannabinol. Psychopharmacology (Berl) 163: 111-117.

Bissiere S, Humeau Y, Luthi A (2003). Dopamine gates LTP induction in lateral amygdala by suppressing feedforward inhibition. Nat Neurosci 6: 587-592.

Carlin AS, Bakker CB, Halpern L, Post RD (1972). Social facilitation of marijuana intoxication: impact of social set and pharmacological activity. J Abnorm Psychol 80: 132-140.

Cravatt BF, Demarest K, Patricelli MP, Bracey MH, Giang DK, Martin BR et al (2001). Supersensitivity to anandamide and enhanced endogenous cannabinoid signaling in mice lacking fatty acid amide hydrolase. Proc Natl Acad Sci USA 98: 9371-9376.

Davis M (2002). Neural circuitry of anxiety and stress disorders. In: Davis KL, Charney D, Coyle JT, Nemeroff C (eds). Neuropsychopharmacology: The Fifth Generation of Progress. American College of Neuropsychopharmacology: Philadelphia, PA. pp 931-951.

Day HE, McKnight AT, Poat JA, Hughes J (1994). Evidence that cholecystokinin induces immediate early gene expression in the brainstem, hypothalamus and amygdala of the rat by a CCKA receptor mechanism. Neuropharmacology 33: 719-727.

Degenhardt L, Hall W, Lynskey M (2001). The relationship between cannabis use, depression and anxiety among Australian adults: findings from the National Survey of Mental Health and Well-Being. Soc Psychiatry Psychiatr Epidemiol 36: 219-227.

Duarte C, Alonso R, Bichet N, Cohen C, Soubrie P, Thiebot MH (2004). Blockade by the cannabinoid CB1 receptor antagonist, rimonabant (SR141716), of the potentiation by quinelorane of food-primed reinstatement of food-seeking behavior. Neuropsychopharmacology 29: 911-920.

French ED, Dillon K, Wu X (1997). Cannabinoids excite dopamine neurons in the ventral tegmentum and substantia nigra. Neuroreport 8: 649-652.

Gessa GL, Melis M, Muntoni AL, Diana M (1998). Cannabinoids activate mesolimbic dopamine neurons by an action on cannabinoid CB1 receptors. Eur J Pharmacol 341: 39-44.

Giuffrida A, Rodriguez de Fonseca F, Nava F, Loubet-Lescoulie P, Piomelli D (2000). Elevated circulating levels of anandamide after administration of the transport inhibitor, AM404. Eur J Pharmacol 408: 161-168.

Giuliani D, Ferrari F, Ottani A (2000). The cannabinoid agonist HU 210 modifies rat behavioural responses to novelty and stress. Pharmacol Res 41: 47-53. 
Gregg JM, Small EW, Moore R, Raft D, Toomey TC (1976). Emotional response to intravenous delta9tetrahydrocannabinol during oral surgery. J Oral Surg 34: 301-313.

Hillard CJ, Edgemond WS, Campbell WB (1995). Characterization of ligand binding to the cannabinoid receptor of rat brain membranes using a novel method: application to anandamide. J Neurochem 64: 677-683.

Hsieh C, Brown S, Derleth C, Mackie K (1999). Internalization and recycling of the CB1 cannabinoid receptor. J Neurochem 73: 493-501.

Jarrahian A, Manna S, Edgemond WS, Campbell WB, Hillard CJ (2000). Structure-activity relationships among $\mathrm{N}$-arachidonylethanolamine (Anandamide) head group analogues for the anandamide transporter. J Neurochem 74: 2597-2606.

Jones RT (1971). Marihuana-induced 'high': influence of expectation, setting and previous drug experience. Pharmacol Rev 23: 359-369.

Kathuria S, Gaetani S, Fegley D, Valino F, Duranti A, Tontini A et al (2003). Modulation of anxiety through blockade of anandamide hydrolysis. Nat Med 9: 76-81.

Katona I, Rancz EA, Acsady L, Ledent C, Mackie K, Hajos N et al (2001). Distribution of CB1 cannabinoid receptors in the amygdala and their role in the control of GABAergic transmission. J Neurosci 21: 9506-9518.

Kearn CS, Greenberg MJ, DiCamelli R, Kurzawa K, Hillard CJ (1999). Relationships between ligand affinities for the cerebellar cannabinoid receptor $\mathrm{CB} 1$ and the induction of GDP/GTP exchange. J Neurochem 72: 2379-2387.

Lastres-Becker I, de Miguel R, De Petrocellis L, Makriyannis A, Di Marzo V, Fernandez-Ruiz J (2003). Compounds acting at the endocannabinoid and/or endovanilloid systems reduce hyperkinesia in a rat model of Huntington's disease. J Neurochem 84: 1097-1109.

MacLean KI, Littleton JM (1977). Environmental stress as a factor in the response of rat brain catecholamine metabolism to delta8tetrahydrocannabinol. Eur J Pharmacol 41: 171-182.

Manzanares J, Corchero J, Fuentes JA (1999). Opioid and cannabinoid receptor-mediated regulation of the increase in adrenocorticotropin hormone and corticosterone plasma concentrations induced by central administration of delta(9)tetrahydrocannabinol in rats. Brain Res 839: 173-179.

Marin S, Marco E, Biscaia M, Fernandez B, Rubio M, Guaza C et al (2003). Involvement of the kappa-opioid receptor in the anxiogenic-like effect of $\mathrm{CP} 55,940$ in male rats. Pharmacol Biochem Behav 74: 649-656.

Marsicano G, Wotjak CT, Azad SC, Bisogno T, Rammes G, Cascio MG et al (2002). The endogenous cannabinoid system controls extinction of aversive memories. Nature 418: 530-534.
Matsuda LA, Bonner TI, Lolait SJ (1993). Localization of cannabinoid receptor mRNA in rat brain. J Comp Neurol 327: 535-550.

McDonald AJ, Mascagni F (2001). Localization of the CB1 type cannabinoid receptor in the rat basolateral amygdala: high concentrations in a subpopulation of cholecystokinin-containing interneurons. Neuroscience 107: 641-652.

McGregor IS, Arnold JC, Weber MF, Topple AN, Hunt GE (1998). A comparison of delta 9-THC and anandamide induced c-fos expression in the rat forebrain. Brain Res 802: 19-26.

Naliboff BD, Rickles WH, Cohen MJ, Naimark RS (1976). Interactions of marijuana and induced stress: forearm blood flow, heart rate, and skin conductance. Psychophysiology 13: 517-522.

Ng LK, Lamprecht F, Williams RB, Kopin IJ (1973). Delta 9tetrahydrocannabinol and ethanol: differential effects on sympathetic activity in differing environmental setting. Science 180: $1368-1369$.

Onaivi ES, Chakrabarti A, Gwebu ET, Chaudhuri G (1995). Neurobehavioral effects of delta 9-THC and cannabinoid (CB1) receptor gene expression in mice. Behav Brain Res 72: 115-125.

Pare D, Royer S, Smith Y, Lang EJ (2003). Contextual inhibitory gating of impulse traffic in the intra-amygdaloid network. Ann NY Acad Sci 985: 78-91.

Patel S, Hillard CJ (2003). Cannabinoid-induced Fos expression within A10 dopaminergic neurons. Brain Res 963: 15-25.

Quirk GJ, Gehlert DR (2003). Inhibition of the amygdala: key to pathological states? Ann NY Acad Sci 985: 263-272.

Quirk GJ, Likhtik E, Pelletier JG, Pare D (2003). Stimulation of medial prefrontal cortex decreases the responsiveness of central amygdala output neurons. J Neurosci 23: 8800-8807.

Reilly D, Didcott P, Swift W, Hall W (1998). Long-term cannabis use: characteristics of users in an Australian rural area. Addiction 93: 837-846.

Royer S, Martina M, Pare D (1999). An inhibitory interface gates impulse traffic between the input and output stations of the amygdala. J Neurosci 19: 10575-10583.

Royer S, Martina M, Pare D (2000). Polarized synaptic interactions between intercalated neurons of the amygdala. J Neurophysiol 83: 3509-3518.

Sah P, Faber ES, Lopez De Armentia M, Power J (2003). The amygdaloid complex: anatomy and physiology. Physiol Rev 83: 803-834.

Szuster RR, Pontius EB, Campos PE (1988). Marijuana sensitivity and panic anxiety. J Clin Psychiatry 49: 427-429.

Thomas H (1996). A community survey of adverse effects of cannabis use. Drug Alcohol Depend 42: 201-207.

Tsou K, Brown S, Sanudo-Pena MC, Mackie K, Walker JM (1998). Immunohistochemical distribution of cannabinoid CB1 receptors in the rat central nervous system. Neuroscience 83: 393-411. 